\title{
PENANAMAN NILAI-NILAI MULTIKULTURAL YANG DIPENGARUHI OLEH KOMPETENSI KOMUNIKASI GURU DI SEKOLAH DASAR INKLUSI TRIRENGGO, YOGYAKARTA
}

\author{
Dwi Kartikawati ${ }^{1 *}$, Djudjur Luciana Rajagukguk ${ }^{2}$, Yayu Sriwartini $^{3}$ \\ 1.23 Faculty of Social and Political Science, Universitas Nasional Jakarta, Indonesia.
}

\begin{tabular}{l} 
ARTICLE INFORMATION \\
\hline Submitted: 10 August 2019 \\
Review : 19 August 2019 \\
Accepted : 21 November 2019 \\
Available online: December 2019 \\
KEYwORDS \\
\hline Communication Competency; Multicultural Values; \\
Inclusive School \\
CoRRESPONDENCE \\
\hline *E-mail: dookartika@yahoo.com
\end{tabular}

\section{A. PENDAHULUAN}

$\mathrm{P}$ endidikan adalah suatu proses dalam rangka memengaruhi siswa agar dapat menyesuaikan diri sebaik mungkin terhadap lingkungannya dan dengan demikian akan menimbulkan perubahan dalam dirinya yang memungkinkan untuk berfungsi secara adekuat dalam kehidupan masyarakat (Hamalik, 2017: 79). Guru memiliki peran sangat penting dan luas (Hamalik,2017:123). Guru harus memiliki penguasaan pengetahuan di samping ketrampilan-ketrampilan lainnya. Salahsatu peran penting guru dalam pendidikan adalah kemampuan untuk berkomunikasi secara efektif sehingga proses tranfer ilmu dapat tersampaikan dengan baik. Peranan penting komunikasi ini juga terjadi pada lingkungan sekolah dalm proses belajar mengajar yang memerlukan komunikasi yang efektif antara guru dan peserta didiknya sehingga proses penyampaian informasi dapat berjalan sesuai tujuan dari pembelajaran itu.

\begin{abstract}
A B S T R A C T
This research focused on the urgency of teachers' communication competence in inculcating multicultural values at elementary schools, in this case, the inclusive elementary school of Trirenggo, Yogyakarta. Communication skills are an essential competency for teachers as stated in the Regulation of the Minister of Education No. 16 of 2007 dated May $4^{\text {th }}$, 2007. Teachers, as communicators, are the main factor in establishing effective communication in the learning process. In this case, a teacher with excellent communication skills would substantially determine a school's success in the implementation of multicultural values. In order to analyze the subject, this study used a qualitative method, and the data were collected from three respondents from the inclusive elementary school of Trirenggo, Yogyakarta. The results indicated that teachers' communication competency which consisted of three aspects, i.e. motivation, knowledge, and skills, was urgently required in order to achieve teaching goals. A competent teacher would significantly be able to establish a positive atmosphere and influence among students, thus, enable them to effectively inculcate the designated values. At this school, the multicultural values were integrated into teaching subjects, students' assessment, specified learning methods, character development, and regular group activities.
\end{abstract}

Untuk itu guru perlu memiliki kompetensi komunikasi. Kompetensi komunikasi adalah kemampuan seseorang dalam melakukan tindak komunikasi secara efektif dan berhasil (Purwasito, 2015: 284). Kompetensi komunikasi merujuk pada kemampuan seseorang dalam berkomunikasi secara efektif. Hal ini selaras juga standar kualitas akademik dan kompetensi guru yang tertuang dalam lampiran Peraturan Menteri Pendidikan Nasional nomor 16 tahun 2007 tanggal 4 Mei 2007 yang menyatakan bahwa kemampuan berkomunikasi merupakan kemampuan inti ke-7 yang harus dimiliki guru. Terdiri dari dua hal yaitu pertama: bahwa seorang guru harus memahami berbagai strategi berkomunikasi yang efektif, empatik, dan santun, secara lisan, tulisan, dan/atau bentuk lain. Kedua, bahwa guru dituntut untuk memiliki kompetensi berkomunikasi secara efektif, empatik, dan santun dengan peserta didik dengan bahasa yang khas dalam interaksi kegiatan/permainan yang mendidik yang terbangun dengan cara antara lain: (a) penyiapan kondisi psikilogis 168 | P a g e 
peserta didik untuk ambil bagian dalam permainan melalui bujukan dan contoh, (b) ajakan kepada peserta didik untuk ambil bagian, (c) respon peserta didik terhadap ajakan guru, dan (d) reaksi guru terhadap respons peserta didik, dan seterusnya. Kompetensi komunikasi sangat penting dijadikan landasan pemikiran komunikasi, terutama dalam komunikasi multikultural yang mencakup pengetahuan tentang peran lingkungan (contexts) dalam memengaruhi kandungan isi pesan (contents) dan bentuk (pattern) pesan komunikasi (Purwasito, 2015: 24285).

Riset-riset mengenai kompetensi komunikasi ini dapat ditelusuri dari penelitian Alfikalia \& Maharani yang berjudul "Faktor-faktor Pendukung Kompetensi Komunikasi Interpersonal: Studi Kasus pada Mahasiswa Tingkat Pertama di Universitas Paramadina" (Alfikalia \& Maharani, 2009), yang menyimpulkan bahwa perbedaan kemampuan komunikasi interpersonal antara mahasiswa di antara program studi-program studi yang menjadi obyek risetnya dilihat dari pengalaman organisasi serta frekwensi bicara di muka umum, serta konteks terjadinya komunikasinya. Sementara penelitian yang meneliti khusus pada kompetensi komunikasi guru dapat dilihat dari penelitian Wulaandari (2013), yang berjudul: "Kompetensi Komunikasi Guru dalam Kegiatan Belajar Mengajar Berbasis Student Center Learning di SMA N 9 Semarang." Hasil penelitian menunjukkan bahwa penilaian murid terhadap kompetensi komunikasi guru dalam kegiatan belajar mengajar berbasis student center learning (SCL) di SMA N 9 Semarang, tergolong dalam kategori kompeten (Wulandari, 2013). Dari rangkaian penelitian yang sudah pernah dilakukan para peneliti terdahulu, riset penulis ini memiliki banyak perbedaan, khususnya penulis melihat pada aspek kompetensi komunikasi guru dalam upaya menanamkan nilai-nilai multikultural di sekolah inklusi. Kompetensi komunikasi dalam penelitian ini meliputi ketiga faktor yaitu motivasi, pengetahuan dan ketrampilan. Sekolah inklusi adalah sekolah khusus yang di dalamnya ada anak-anak reguler dan anak anak dengan berkebutuhan khusus belajar bersama dalam satu kelas. Ini yang menjadi kekuatan penelitian penulis, mengingat kompetensi komunikasi guru di sekolah semacam ini wajib dimiliki oleh para guru dan perlu di tingkatkan.

Kompetensi komunikasi merujuk pada dua konsep yaitu kompetensi dan komunikasi. Pengertian kompetensi adalah kemampuan seseorang yang meliputi motivasi, keterampilan, dan pengetahuan dalam melakukan sesuatu kegiatan atau pekerjaan tertentu sesuai dengan standar-standar yang telah ditetapkan. Sedangkan komunikasi merupakan aktivitas dasar manusia. Dengan berkomunikasi, manusia dapat saling berhubungan satu sama lain baik dalam kehidupan sehari-hari. Tidak ada manusia yang tidak terlibat dalam komunikasi. Komunikasi memiliki peranan yang sangat penting dalam kehidupan manusia, baik secara individu, kelompok, maupun dalam organisasi. Menurut Carl I Hovland, komunikasi adalah suatu proses di mana individu mengirimkan stimulus (biasanya simbol-simbol verbal) untuk memodifikasi perilaku individu lainnya (Iriantara \& Syaripudin, 2018: 6). Komunikasi yang berkualitas adalah komunikasi yang efektif.

Komunikasi efektif merujuk pada bagaimana dalam sebuah proses interaksi komunikasi, pesan oleh komunikator dapat tersampaikan dengan baik, dan memberi efek pada si penerima pesan (komunikator). Komponen kompetensi komunikasi motivasi (motivation), ketrampilan (skill), pengetahuan (Knowledge) (Samovar \& Porter, 2010). Kompetensi komunikasi antara lain motivasi untuk berkomunikasi, pengetahuan yang dimiliki dan kemampuan komunikasi yang sesuai, memiliki sensitivitas dan karakter. Faktor motivasi adalah menjadi daya dorong untuk melakukan komunikasi (Samovar \& Porter, 2010). Sedangkan pengetahuan adalah kegiatan komunikator dalam mencari informasi mengenai lawan bicaranya sehingga dapat mengurangi tingkat kecemasan dalam berkomunikasi dengan orang lain. Ketrampilan adalah kemampuan dalam berkomunikasi yang baik, proses penyampaian pesan atau informasi dapat secara mudah dipahami oleh orang lain yang dituju. Motivasi adalah proses di mana aktivitas yang terarah pada suatu tujuan tertentu didorong dan dipertahankan (Purwanto, 2014: 219). Biasanya orang tertindak karena suatu alasan untuk mencapai tujuan. Pengetahuan komunikasi dalah kegiatan komunikator dalam mencari informasi lawan bicaranya supaya dapat menguragi tingkat kecemasan dalam berkomunikasi. Seorang individu harus memahami serta menyadari norma, aturan, serta harapan dari individu lainnya yang memiliki latar belakang yang berbeda.

Untuk menjadi kompeten, dibutuhkan dua jenis pengetahuan yaitu pengetahuan konten dan pengetahuan prosedural (Haryanti, 2013: 21). Dengan pengetahuan konten meliputi pengetahuan meliputi topik apa, kata-kata yang digunakan, pemahaman situasi danseterusnya yang dibutuhkan dalam suatu situasi, diharapkan guru dapat belajar dan mengajar dengan sistem inkuiri. Pengetahuan prosedural merujuk pada pengetahuan bagaimana cara menyusun, merencanakan, dan mentransfer pengetahuan yang dimilki dalam situasi tertentu. Ketrampilan komunikasi merupakan kemampuan yang dapat membimbing seseorang untuk menghadirkan sebuah perilaku tertentu yang cukup dan mampu mendukung proses komunikasi secara tepat dan efektif. Untuk mengurangi ketidakpastian, seorang komunikator sedapat mungkin harus memiliki tiga ketrampilan yaitu empati, berperilaku seluwes mungkin, dan kemampuan 
mengurangi ketidakpastian. Kompetensi komunikasi dapat dilakukan dengan mengamati perilaku kita dengan mengidentifikasi diri dengan cara terbuka dalam komunikasi, memahami gaya komunikasi, dan memonitor diri sendiri, mendengarkan. Communication knowledge The next major component of the competence model is knowledge...Questions were generated addressing the three major dimensions of competence pinpointed in this research: empathy, adaptability, and interaction management (A.Rahman, 2015: 262). Keseluruhan kompetensi komunikasi itu sangat diperlukan untuk dimiliki para guru terutama dalam proses penanaman nilai-nilai multikultural. Kemampuan guru sebagai bagian dari masyarakat untuk berkomunikasi dan bergaul secara efektif dengan peserta didik, sesama pendidik, tenaga kependidikan, orang tua atau wali peserta didik, dan masyarakat sekitar menjadi faktor yang menentukan keberhasilan pembelajaran.

Dalam riset ini menekankan kompetensi komunikasi guru ini mempengaruhi dalam penanaman nilai-nilai multikultural di tingkat sekolah dasar inklusi. Guru harus memainkan peranan utama dalam proses tersebut. Guru dapat melakukan dengan cara menyadari budaya diri sendiri, mengamati perilaku pribadi diri, memahami gaya komunikasi diri, dan memonitor dirinya sendiri antara lain: (1) Pemahaman terhadap berbagai proses komunikasi dalam berbagai konteksnya. (2). Kemampuan perilaku komunikasi verbal dan non-verbal secara tepat. (3) Berorientasi pada sikap positif terhadap komunikasi. Kemampuan komunikasi merupakan keterampilan utama yang harus dimiliki oleh guru. Jika keterampilan komunikasi dimiliki maka akan sangat besar membantu meminimalisir miss komunikasi sekaligus membuka peluang sukses bagi para siswa.

Dalam penanaman nilai-nilai multikultural tersebut melalui pendidikan multikultural guru tentunya berusaha mengomunikasikan cara hidup menghormati, tulus, dan toleran terhadap keberagaman yang ada dimasyarakat. Pendidikan multikultural adalah sebuah kebijakan sosial yang didasarkan pada prinsip-prinsip pemeliharaan budaya dan saling memiliki rasa hormat antara seluruh kelompok budaya di dalam masyarakat (Al Hakim \&Utari, 2018:2) Menurut Zulqarnain (2016: 198), pendidikan multikultural memiliki lima dimensi yang saling berkaitan, yakni: (a) Content Integration: Mengintegrasikan berbagai budaya dan kelompok untuk mengilustrasikan konsep mendasar, generalisasi, dan teori dalam mata pelajaran/disiplin ilmu; (b) The Knowledge Contruction Process: Membaca siswa untuk memahami implikasi budaya ke dalam sebuah mata pelajaran (disiplin); (c) $A n$ Pedagogy: Menyesuaikan metode pengajaran dengan cara belajar siswa dalam rangka memfasilitasi prestasi akademik siswa yang beragam baik dari segi ras, budaya maupun sosial; (d) Prejudice Reduction: Mendefinisikan karakteristik ras siswa dan menentukan metode pengajaran mereka; dan (e) Melatih kelompok untuk berpartisipasi dalam kegiatan olahraga, berinteraksi dengan seluruh staf dan siswa yang berbeda etnis dan ras dalam upaya menciptakan budaya akademik. Dalam pembelajaran pada umumnya, bentuk pembelajaran cooperative learning adalah kegiatan belajar mengajar yang dilakukan oleh guru dalam bentuk kelompokkelompok kecil, siswa belajar dan bekerjasama untuk sampai pada pengalaman belajar yang optimal, baik pengalaman individu maupun kelompoknya (Sembiring \& Maputra, 2015:3).

Dengan demikian keterampilan komunikasi yang baik yang dimiliki guru akan memberikan iklim belajar yang positif dalam proses penanaman nilai-nilai multikultural yang berpengaruh pada perilaku dan kemampuan belajar siswa. Penelitian ini memfokuskan pada sekolah SD Trirenggo Yogyakarta yang merupakan sekolah inklusi. Sekolah Dasar Negeri 1 Trirenggo terletak di Klembon, Trirenggo, Bantul, Yogyakarta. Sekolah ini adalah perpaduan antara SD Klembon dan SD Tanubayan tahun 2007 dan diberi nama SD Negeri 1 Trirenggo Yogyakarta. Sekolah inklusi dalam penyelenggaraan pendidikannya melaksanakan pendidikan inklusif. Pendidikan inklusif adalah penyelenggaraan pendidikan yang menyatukan anak-anak berkebutuhan khusus dengan anak-anak normal pada umumnya untuk belajar (Wahyudi \& Kristiawati, 2016: 6). Kata inklusi berasal dari bahasa Inggris yaitu inclusion, istilah yang dilihat sebagai deskripsi yang lebih positif dalam menyatukan anak-anak memiliki hambatan dengan cara yang realistis dan kompehensif dalam pendidikan secara menyeluruh (Smith, 2006: 46).

SD Trirenggo dipimpin oleh kepala sekolah yang bernama Istiani Nurhasanah, M.Pd. selain itu ada sekitar 17 tenaga guru yang terdiri dari 12 guru kelas, 1 guru Agama Islam, 2 guru olah raga, 1 guru karawitan, dan 1 guru batik. Negeri 1 Trirenggo ini merupakan sekolah penyelenggara pendidikan inklusi. SD Negeri 1 Trirenggo juga merupakan sekolah model pendidikan berbasis budaya melalui Surat Keputusan Kepala Dinas Pendidikan, Pemuda, dan Olahraga Daerah Istimewa Yogyakarta Nomor 1980 Tahun 2014. Selain itu, SD Negeri 1 Trirenggo juga masuk nominasi Sekolah Sehat tingkat provinsi dan dalam penilaian menuju sekolah Adiwiyata.

Dengan model sekolah inklusi ini memungkinkan anak anak yang berkebutuhan khusus memperoleh ilmu pengetahuan di sekolah umum sebagaimana sebagaimana yang diperoleh oleh anak anak normal. Pembelajaran berbasis multikultural berusaha memberdayakan siswa untuk mengembangkan rasa hormat kepada orang yang berbeda budaya, memberi kesempatan untuk bekerja bersama dengan orang atau kelompok orang yang berbeda. Hal itu dikarenakan keterampilan komunikasi tidak 
hanya penting untuk proses komunikasi namun juga faktor yang dapat membantu keberhasilan siswa dalam mengelola emosi dan sosial mereka. Keterampilan komunikasi dan motivasi bekerja merupakan dua hal yang penting untuk dapat meningkatkan profesionalisme guru dalam proses pembelajaran untuk proses knowledge sharing pada siswanya. Ketrampilan Komunikasi yang baik sangat penting dimiliki oleh guru/ pendidik untuk dapat meningkatkan kinerja belajar para siswa. Dari uraian di atas, maka rumusan dalam penelitian ini adalah: "Bagaimanakah penanaman nilai-nilai multikultural dipengaruhi oleh kompetensi komunikasi guru di Sekolah Dasar Trirenggo Yogyakarta?". Adapun tujuan penelitian antara lain: untuk mengetahui bagaimana penanaman nilai-nilai multikultural ini dapat dipengaruhi oleh kompetensi komunikasi guru di SD Trirenggo Yogyakarta. Manfaat penelitian ini, selain memberikan manfaat akademik, juga memerikan manfaat praktis terutama bagi para guru untuk dapat lebih meningkatkan kompetensi komunikasinya. Manfaat yang terakhir yang diharapkan adalah manfaat sosial, yang ditujukan pada masyarakat banyak untuk menyadari bahwa dengan kompetensi komunikasi yang baik dari guru sekolah inklusi maka akan sangat mendukung tujuan pendidikan terutama di sekolah inklusi semakin membaik ke depannya.

\section{B. METODE}

$\mathrm{P}$ enelitian ini menggunakan metode penelitian kualitatif dengan pendekatan studi kasus tunggal. Karakteristik Penelitian kualitatif antara lain (Cresswell, 2010:15): dilakukan pada kondisi yang alamiah, Peneliti sebagai instrumen kunci (researcher as key instrument), Rancangan yang berkembang (emergent design); bagi para peneliti kualitatif, proses penelitian selalu berkembang dinamis, Beragam sumber data (multiple sources of data); para peneliti kualitatif biasanya memilih mengumpulkan data dari beragam sumber, seperti wawancara, observasi, dan dokumentasi, ketimbang hanya bertumpu pada satu sumber data saja. Analisis data induktif (inductive data analysis); para peneliti kualitatif membangun pola-pola, kategori-kategori, dan tema-temanya dari bawah ke atas (induktif), dengan mengolah data ke dalam unit-unit informasi yang lebih abstrak. Pada penelitian kualitatif ini dilakukan untuk memahami masalah sosial dengan menciptakan gambaran menyeluruh dan kompleks yang disajikan dengan kata-kata, melaporkan pandangan terinci yang diperoleh dari sumber informasi, serta dilakukan dalam latar alamiah (Gunawan, 2017: 81). Data yang terkumpul berbentuk kata-kata atau gambar, sehingga tidak menekankan pada angka, tetapi lebih menekankan pada proses daripada produk atau outcome, bersifat penafsiran (interpretive, pandangan menyeluruh (holistic account); para penelitian kualitatif berusaha membuat gambaran kompleks dari suatu masalah atau isu yang diteliti. Sedangkan pendekatan studi kasus, melihat pada keutuhan dari objek perlu dipertahankan. Sumber data berupa data primer diperoleh langsung dari hasil pengamatan (observasi), wawancara langsung dengan informan baik secara individu maupun secara kelompok. Teknik sampling menggunakan purposive sampling. Purposive sampling adalah teknik pengambilan sampel sumber data dengan pertimbangan tertentu (Zamzami. Lucky,\& Hendrawati. 2014: 41). Pertimbangan tertentu ini, maksudnya adalah orang yang dianggap lebih mengetahui dan memiliki banyak informasi tentang objek penelitian. Teknik pengumpulan data dengan wawancara, observasi dan analisis dokumen. Wawancara dilakukan terhadap 3 (tiga) informan yaitu informan 1 (Kepala Sekolah), informan 2 (Guru Mata Pelajaran PKN) dan informan 3 (Guru Mata Pelajaran IPS). Data collections (Pengumpulan Data), adalah fase pengumpulan data dengan teknik-teknik pengumpulan data. Pada penelitian ini, teknikteknik pengumpulan data yang dipergunakan adalah (1) Wawancara, (2) Observasi, Dokumentasi.

Dalam analisis data dilakukan secara interaktif dan berlangsung secara terus menerus sampai tuntas, sehingga data yang diperoleh dapat dipandang telah jenuh. Analisis data dengan menggunakan model ini, terbagi menjadi empat element penting, yakni: data collection, data reduction, data display, dan conclusion/ drawing/verivication. Data Reduction (Reduksi Data), ini merupakan proses reduksi data yang telah dikumpulkan. Data yang telah dikumpulkan dalam penelitian secara relatif cukup banyak oleh karena itu penulis perlu mereduksi data-data yang dipandang tidak relevan dengan penelitian. Mereduksi data dapat dipahami sebagai sebuah upaya untuk merangkum, memilih hal-hal yang benar-benar esensial dan terkait dengan penelitian. Data Display (Penyajian Data). Setelah data-data direduksi maka proses penyajian data dapat dilakukan. Umumnya, dalam penelitian kualitiatif, penyajian data dalam bentuk teks yang bersifat naratif. Conclusion Drawing/Verification (Penarikan Kesimpulan dan Verifikasi), setelah data direduksi dan disajikan maka kesimpulan awal mulai ditarik namun hanya bersifat sementara. Kesimpulan ini harus diverivikasi atau diuji keabsahannya agar dapat diketahui benar atau tidaknya data yang telah dikumpulkan. Pada uji keabsahan data, dilakukan degan menggunakan triangulasi sumber dan teknik, yakni dengan mencocokan hasil observasi penulis dengan keterangan narasumber dan juga melakukan Triangulasi sumber

\section{HASIL DAN PEMBAHASAN}


$\mathrm{P}$ ada hasil dan pembahasan berisi hasilhasil temuan penelitian dan pembahasannya. Dalam melakukan kegiatan tersebut maka diperlukan kemampuan komunikasi yang baik dengan anak didiknya. Kemampuan komunikasi menjadi keterampilan yang penting untuk dimiliki oleh guru. Keterampilan komunikasi pada guru sangat membantu dalam proses penanaman nilai-nilai multikultural di sekolah dasar inklusi karena terkait dengan kemampuannya untuk mengko-munikasikan nilai nilai tersebut. Dengan memiliki keterampilan komunikasi yang baik, proses penyampaian pesan atau informasi dapat secara mudah dipahami oleh orang lain yang dituju. Kemampuan komunikasi yang baik pada guru diharapkan dapat meningkatkan kinerja individu ataupun sekolah sehingga membantu proses penanamana nilai-nilai multikultural. Guru berupaya menjadi komunikator yang memiliki peran penting dalam menentukan keefektifan komunikasi yang dilakukan. Keberhasilan komunikasi yang dilakukan bertujuan untuk mempengaruhi komunikan sebagaimana arah perubahan yang diinginkan.

Lingkungan komunikasi yang positif dapat mendukung kesempatan bagi peneliti untuk belajar mengenai keterampilan dan bagaimana berkomunikasi lebih baik. Kemampuan komunikasi yang baik maka akan mempermudah proses transfer knowledge, karena akan mudah saling memahami informasi yang bertukar. Keterampilan komunikasi verbal dan non-verbal yang perlu dikuasai oleh peneliti adalah komunikasi interpersonal yang mendukung dalam menamamkan nilai-nilai pendidikan multikultural, sehingga seorang guru tidak hanya dituntut untuk mampu secara profesional mengajarkan mata pelajaran yang diampunya akan tetapi harus mampu menanamkan nilai-nilai keberagaman yang inklusif.

Kompetensi komunikasi yang pertama yang harus dimiliki guru adalah motivasi dalam komunikasi dengan anak-anak didik. Berbagai upaya untuk meningkatkan motivasi dalam kegiatan komunikasi untuk mendukung belajar di sekolah, pihak SD Trirenggo menurut Informan 1 yang disetujui juga oleh informan 2 dan 3, bahwa sekolah ini memiliki beberapa langkah yang dilakukan guru, antara lain "memberikan pujian". Apabila ada siswa yang berhasil menyelesaikan tugasnya dengan baik, maka perlu diberikan pujian. Pujian itu bisa dikatakan sebagai bentuk reinforcement yang positif dan memberikan motivasi yang baik bagi siswa. Pemberiannya juga harus pada waktu yang tepat, sehingga akan memupuk suasana yang menyenangkan dan mempertinggi motivasi belajar serta sekaligus akan membangkitkan harga diri siswa. Dalam hal gaya komunikasi yang dilakukan dengan siswa baik siswa reguler dan juga siswa berkebutuhan khusus harus disesuaikan dengan situasi yang ada. Menurut pengakuan kepala sekolah selaku informan 1:

\begin{abstract}
"Peran dan fungsi kepala sekolah harus bisa menjadi contoh bagi seluruh warga sekolah dengan amanah yang telah diberikan. Harus bisa berfungsi sebagai sebagai leader atau pemimpin yang memiliki jiwa besar, sabar, percaya diri, tanggungjawab, mampu menjadi teladan yang yang juga paling penting adalah memiliki emosi yang stabil dan mampu menjalin komunikasi yang baik terutama dengan anak-anak"
\end{abstract}

Dalam hal knowledge atau pengetahuan, guru perlu memiliki pengetahuan dalam hal konten yaitu pengetahuan mengenai apa akan diinfor masikan dan pengetahuan procedural adalah pengetahuan bagaimana cara menyampaikan pesan yang diciptakan. Dalam hal skill atau ketrampilan. Dalam pengertian ini ini guru menerapkan pola-pola komunikasi empati melalui ketrampilan berbahasa yang baik, verbal dan non verbal dan mau mendengarkan, dapat berperilaku seluwes mungkin, dan memiliki kemampuan mengurangi ketidakpastian. Kompetensi komunikasi sebagaimana dinyatakan oleh Purwasito (2017: 284), bahwa ketrampilan komunikasi adalah kemampuan dalam bertindak komuikasi secara efektif dan berhasil. Kegiatan belajar mengajar yang berkaitan dengan kegiatan dalam menanamkan nilai-nilai multikultural diimplementasikan melalui pembelajaran formal dan juga kegiatan non formal; yang menekankan menekankan pada aspek moral dan akhlak terpuji yang termuat dalam materi pelajaran sangat urgen membutuhkan kemampuan komu nikasi yang baik atau dengan kata lain memiliki kompetensi komunikasi. Kompetensi komunikasi diperlukan dalam penanaman nilai-nilai multi kultural yang meliputi lima kegiatan pendidikan multikultural yaitu:

a. Content Integration: Mengintegrasikan berbagai budaya dan kelompok untuk mengilus trasikan konsep mendasar, gene ralisasi, dan teori dalam mata pelajaran/ disiplin ilmu. Bentuk kongkrit yang dilakukan yang ditemukan dalam penelitian ini adalah mengintegrasikan nilai-nilai multikultural da lam mata pelajaran. The Knowledge Contruc tion Process: Mengamati siswa untuk memahami implikasi budaya ke dalam pelajaran (melatih disiplin). Bentuk kongkrit yang dilakukan yang ditemukan dalam penelitian ini adalah proses konstruksi pengetahuan dilakukan dengan memahami siswa yang berbeda dalam pemberian materi pembelajaran dan menerapkan kedisiplinan pembelajaran.

b. An Pedagogy: Menyesuaikan metode 
pengajaran dengan cara belajar siswa dalam rangka memfasilitasi prestasi akademik siswa yang beragam baik dari segi ras, budaya maupun sosial. Bentuk kongkrit yang dilakukan yang ditemukan dalam penelitian ini adalah menggunakan metode pembelajaran khusus-kurikulum adaptif. Hal tersebut selaras dengan informan 2 yaitu guru mata pelajaran PKN di SD Trirenggo yang mengatakan: " kita sebagai guru harus mampu melakukan persiapan RPP, mempersiapkan media yang disesuaikan dengan kemampuan siswa. Metode yang dilakukan harus kreatif. Kalau hanya ceramah aja maka jadi terbatas dan siswa mudah bosan. Maka bisa dengan memberi kertas tadi misalnya tentang toleransi, tentang hemat, dan Iain-lain. Kalau anak inklusi cukup nulis. Udah nulis mau aja itu sudah prestasi. Anak inklusi ini memang butuh perhatian lebih maka harus di dampingi." Di sekolah ini guru menerapkan kurikulum yang adaptif dan mampu melihat siswa secara beragam dengan keunikan masing-masing. Sebagai kepala sekolah wajib melakukan motivasi dorongan dengan melakukan komunikasi aktif dengan para guru dan anak didiknya. Salahsatunya seperti pernyataan informan 1 yang dikutip penulis sebagai berikut: "Saya jelaskan semua termasuk ke guru juga. Di jaga komunikasi ke anak anak ataupun orangtua. Karena ga gampang tho (tidak mudah) bu kalau memiliki anak inklusi seperti ini. Dan kita kan ga nyuwun (Bahasa Jawa; tidak meminta). Ada aja perilaku anak anak Anak berkebutuhan khusus yang memancing mancing negatif. Saya wis pesen ke guru guru ojo susah harus sabar."

c. Prejudice Reduction: Mendefenisikan karakteristik siswa dengan pembinaan karakter untuk mengurangi prasangka pada orang lain. Berbagai kegiatan untuk medukung pembinaan karakter peserta didik dilakukan yaitu dengan pengembangan diri. Upaya untuk membentuk watak, karakter dan kepribadian peserta didik yang dilakukan melalui beberapa kegiatan ekstrakurikuler. Sebelumnya sekolah Trirenggo ini anyak yg menganggap sekolah yang isinya anak-anak bodoh karena di dalam pelayanan sekolah ini juga melayani anak-anak berkebutuhan khusus, namun lama-lama pandangan tersebut luntur seiring dengan berbagai macam kegiatan positif yang dilakukan dan juga prestasi sekolahnya. Dalam pelaksanaan pelayanan pendidikan dilakukan kegiatan pengembangan diri yang berupa kegiatan olahraga, kegiatan seni dan budaya seperti karawitan, dan lain lain. Menurut informan 1 yaitu kepala sekolah SD Trirenggo:"Kita dapat memanfaatkan yang ada di sekitar sekolah kita ini, bisa memanfaatkan lapangan misalnya untuk olahraga dan juga mengembangkan diri melalui permainan anak anak, kemudian kantin untuk dimanfaatkan supaya anak anak bisa makan sayur yang ditanam di kebun kita sendiri." Lebih lanjut informan 1 menyatakan: "Saya buat gebrakan 5 gerakan. Ada Program Gemais. Gerakan makan ikan dan sayur. Orang tua di sediakan ikan dan sayur untuk mencegah anemia. SD 1 dulu waktu belum gabung kan seger-seger nah di sini kok kuru-kuru (Bahasa Jawa: kurus kurus). Awalnya kantin 2 meja. Kantin kantin akhirnya jadi unggulan karena masak sayur dari kebon sendiri. Kantin di abmbil dari kebon sekolah. Saya memanfaatkan lahan sempit. Ada terong, kangung, bayam dll. Akhirnya dari badan ketahanan pangan seneng dan akhirnya di bantu juga. Anak anak juga kan jadi hemat dan sehat tho bu wong ambil dari kebon sendiri. Bekal dari rumah bisa nasi. Dan lain lain. Berusaha untuk mandiri yang kalau orang luar banyak menilai sekolah isinya bocah-bocah kemplo (Anak-anak Bodoh), lama-lama orang tidak menilai seperti itu lagi. Alhamdulillah". Jadi sekolah Trirenggo ini dulunya memiliki pandangan stereotype buruk sebagai sekolah yang isi nya anakanak yang tidak pintar. Tetapi seiring dengan waktu dan prestasi yang di raih maka sekolah ini justru berhasil menajdi sekolah Adiwiyata, dan juga banyak prestasi-prestasi yang diraihnya.

d. Melatih kelompok untuk berpartisipasi dalam kegiatan olahraga, berinteraksi dengan seluruh staf dan siswa yang berbeda etnis dan ras dalam upaya menciptakan budaya akademik. Menurut informan 3, dengan bergabungnya anak-anak dalam kelompok maka akan terlihat kerjasama dan saling tolong menolong, termasuk menolong anak anak yang berkebutuhan khusus dan anak anak ABK ini tidak ditinggalkan oleh temantemannya. Dengan kerja kelompok, dapat memberi kesempatan kepada siswa untuk mengembangkan rasa menghargai dan menghormati pribadi temannya, menghargai pendapat orang lain, hal mana mereka telah saling membantu kelompok dalam usahanya mencapai tujuan bersama. Bisa juga untuk mengembangkan bakat kepemimpinan dan mengajarkan keterampailan berdiskusi. Siswa akan menjadi lebih aktif, berusaha mencari solusi atas masalah atau tugas yang dihadapinya dengan melakukan hal tersebut siswa akan menjadi pribadi yang pekerja keras, pantang menyerah dan kemampuan berpikir siswa dalam mencari jalan keluar atas masalahnya semakin meningkat. Siswa akan belajar bagaimana 
menjadi pribadi yang bertanggung jawab terhadap tugas dan amanah yang dibebankan kepadanya selain itu pemberian tugas juga mendidik anak menjadi lebih inisiatif dalam menyelesaikan berbagai masalah.

e. Secara keseluruhan dalam penanamana nilai-nilai multikultural dalam pendidikan akan memposisikan peserta didik sebagai subyek sekaligus obyek pendidikan, yang sesuai dengan ciri peserta didik yaitu berdaya menggunakan kemampuannya dan kemauannya, memiliki keinginan untuk berkembang, memiliki latar belakang sosiokultur yang berbeda, memiliki potensi secara individu. Sedangkan untuk melihat betapa pentingnya kompetensi komunikasi dalam penanaman nilai-nilai multikultural, dapat diliht pada tabel berikut:

Tabel 1. Kompetensi komunikasi guru dalam penanaman nilai-nilai multikultural

\begin{tabular}{|c|c|c|c|}
\hline \multirow{2}{*}{$\begin{array}{l}\text { Penanaman nilai-nilai } \\
\text { multikultural }\end{array}$} & \multicolumn{3}{|c|}{ Kompetensi komunikasi Guru } \\
\hline & Motivasi & Pengetahuan & Ketrampilan atau kemampuan \\
\hline Content Integration & Dalam pemberian motivasi & Memahami pengetahuan & Dengan cara menerapkan \\
\hline $\begin{array}{l}\text { Integrasi dalam } \\
\text { pelajaran }\end{array}$ & $\begin{array}{lr}\text { komunikasi dilakukan } \\
\text { melalui pemberian pujian } \\
\text { dalam capaian mata } \\
\text { pelajaran ketika siswa } \\
\text { menunjukkan } & \text { progres } \\
\text { kemampuan sekecil apapun } \\
\text { yang dicapai. }\end{array}$ & $\begin{array}{l}\text { dalam hal konten isi materi } \\
\text { pembelajaran yang } \\
\text { dituangkan dari } \\
\text { perencanaan pembelajaran } \\
\text { hingga evaluasi dan } \\
\text { prosedur pelaksanaannya }\end{array}$ & $\begin{array}{l}\text { komunikasi empati dan memiliki } \\
\text { sensitivitas terhadap interaksi } \\
\text { yg dilakukn dengan fleksibel, } \\
\text { sabar, empati. } \\
\text { Guru luwes dalam bergaul } \\
\text { dengan peserta didik. } \\
\text { Guru tidak merasa lebih } \\
\text { berkuasa di kelas. } \\
\text { Siswa dianggap sebagai } \\
\text { sahabat oleh guru. }\end{array}$ \\
\hline The Knowledge Contruction & Motivasi diri untuk & Memiliki pengetahuan & Memiliki ketrampilan \\
\hline $\begin{array}{l}\text { Process } \\
\text { pengetahuan dilakukan } \\
\text { dengan memahami siswa } \\
\text { yang berbeda }\end{array}$ & $\begin{array}{l}\text { Derkomunikasl penyiapan } \\
\text { melakukan psikologis peserta } \\
\text { kondisi psian ambil bagian } \\
\text { didik untuk amberajaran } \\
\text { dalam pembelajaran }\end{array}$ & $\begin{array}{l}\text { dasar dalam memanami } \\
\text { latar belakang siswa } \\
\text { dengan segala keunikan } \\
\text { yang dimiliki }\end{array}$ & $\begin{array}{l}\text { dan terbuka pada perbedaan } \\
\text { dalam menjalin komunikasi } \\
\text { yang baik dengan anak didik } \\
\text { yang beragam }\end{array}$ \\
\hline $\begin{array}{lr}\text { An Pedagogy } & \\
\text { Menggunakan } & \text { metode } \\
\text { pembelajaran } & \text { khusus- } \\
\text { kurikulum adaptif } & \end{array}$ & $\begin{array}{l}\text { Dorongan dengan } \\
\text { melakukan komunikasi aktif } \\
\text { dengan para guru dan anak } \\
\text { didiknya dalam penerapan } \\
\text { kurikulum yang fleksibel }\end{array}$ & $\begin{array}{l}\text { Memiliki pengetahuan } \\
\text { dalam berkomunikasi yang } \\
\text { berkaitan dengan metode } \\
\text { pembelajaran }\end{array}$ & $\begin{array}{l}\text { Memiliki } \\
\text { komunikasi dalam tranfer ilmu } \\
\text { yang disesuaikan dengan siswa }\end{array}$ \\
\hline $\begin{array}{l}\text { Prejudice Reduction } \\
\text { Pembinaan karakter untuk } \\
\text { mengurangi prasangka }\end{array}$ & $\begin{array}{l}\text { Dalam kompetensi } \\
\text { komunikasi yang berkaitan } \\
\text { dengan pemberian dorongan } \\
\text { motivasi bahwa semua } \\
\text { manusia adalah sama yang } \\
\text { disampaikan secara verbal } \\
\text { atau dengan media } \\
\text { komunikasi lainnya }\end{array}$ & $\begin{array}{lr}\text { Memiliki } & \text { pengetahuan } \\
\text { dalam } & \text { penyampaian } \\
\text { materi- } & \text { materi } \\
\text { pembelajaran pendukung } \\
\text { untuk } & \text { menghilangkan } \\
\text { perbedaan } & \end{array}$ & $\begin{array}{l}\text { Memiliki ketrampilan } \\
\text { komunikasi empatik dalam } \\
\text { pembinaan karakter }\end{array}$ \\
\hline Melatih dalam kelompok & $\begin{array}{l}\text { Selalu memberikan } \\
\text { dorongan dengan apresiasi } \\
\text { dan pujian terhadap apa } \\
\text { yang di capai anak didik } \\
\text { yang bergabung dalam } \\
\text { dalam kelompok tugas tanpa } \\
\text { membedakan baik anak } \\
\text { reguler ataupun anak-anak } \\
\text { ABK. }\end{array}$ & $\begin{array}{l}\text { Memiliki pengetahuan } \\
\text { pembelajaran dalam bentuk } \\
\text { mengajarkan anak kegiatan } \\
\text { ekstrakulikuler olahraga, } \\
\text { karawitan dan seni } \\
\text { membatik. }\end{array}$ & $\begin{array}{l}\text { Dengan menerapkan } \\
\text { komunikasi yang santun dan } \\
\text { berlatih ketrampilan komunikasi } \\
\text { yang positif dengan tim atau } \\
\text { kelompok }\end{array}$ \\
\hline
\end{tabular}

Sumber: Hasil Olahan Peneliti

Dalam hal gaya komunikasi yang dipilih para guru dari seluruh informan di SD Trirenggo, yaitu 
Tabel 2. Gaya Komunikasi Guru

\begin{tabular}{|c|c|c|}
\hline Sifat Gaya & Karakteristik Komunikasi & Alasan \\
\hline \multicolumn{3}{|l|}{ Komunikasi } \\
\hline Rileks & Tenang, nyaman & Supaya anak-anak merasa nyaman \\
\hline Penuh perhatian & $\begin{array}{l}\text { Pendengar yang baik, memberikan } \\
\text { semangat }\end{array}$ & $\begin{array}{l}\text { Hal ini wajib diberikan karena anak-anak kondisinya } \\
\text { beragam }\end{array}$ \\
\hline Terbuka & $\begin{array}{l}\text { Menyatakan emosi dan perasaan } \\
\text { dengan apa adanya }\end{array}$ & $\begin{array}{l}\text { Dengan terjalinnya keterbukaan, masing-masing } \\
\text { pihak merasa bebas bertindak, saling menjaga } \\
\text { kejujuran }\end{array}$ \\
\hline Ramah & $\begin{array}{l}\text { Menawarkan umpan } \\
\text { dukungan yang positif }\end{array}$ & $\begin{array}{l}\text { Dapat mengetahui kelebihan-kelebihan siswa dan } \\
\text { bukan dilihat dari kelemahannya, guru juga } \\
\text { menghindari kecenderungan untuk membandingkan } \\
\text { siswa dengan siswa lain }\end{array}$ \\
\hline
\end{tabular}

Sumber: Hasil Olahan Peneliti

Dalam pelaksanaannya banyak kelemahan dan kekurangan antara lain seperti yang dinyatakan kepala sekolah (informan 1) sebagai berikut:

"Wah Iha kalau masalah hambatan meniko njih ada (Bahasa Jawa: hambatan ini juga ada). Karena pada dasarnya belum semuanya siap mengingat untuk mengelola sekolah seperti ini itu ya harus panggilan hati, apalagi mesti memahami perbedaan kemampuan meniko. Wong kalau ada pertemuan antar sekolah, sampai dibilang lha kae sekolah sing bocahe kemplo-kemplo (bodoh-bodoh). Yah begitulah bu, kita siap kok. Kita juga manfaatin yang ada di sekolah untuk mendukung pelaksanaan pembelajaran tanpa membedakan dengan baik. Dengan gaya komunikasi yang baik dan terbuka. Karena kalau dilihat dari sarana dan prasarana masih kurang tho bu. Kita buat warna yang menarik. Yang penting semua saling memahami, insyaallah bisa berjalan baik. Begitu bu."

Sehingga dapat disimpulkan dari sisi kekurangan di sekolah ini adalah masih ada beberapa guru yang kurang kompeten dalam komunikasi pembelajaran serta kurangnya wawasan dalam proses pengajaran. Guru guru reguler yang sudah kewalahan dan belum siap terutama dalam hubungan penanganan komunikasi dengan anak anak berkebutuhan khusus. Hambatan lain adalah berasal dari orangtua yang rata-rata menyerahkan sepenuhnya pendidikan anak-anak terutama anak-anak inklusi, terkadang orangtua kurang memahami bahwa pelayanan di sekolah masih sangat terbatas. Bahkan untuk komunikasi dengan orangtua siswa $\mathrm{ABK}$ tertentu cukup menyulitkan karena kekurangpahaman mengenai pendidikan inklusi.

Hambatan lain yang ditemui adalah guru kurang kreatif dan inovatif maka anak didik cepat merasa bosan, jenuh, kurang merasa nyaman saat pembelajaran berlangsung. Informan 2 dan 3 mengakui bahwa terkadang mereka merasa harus berupaya keras untuk aktif dan kreatif dalam pemberian pembelajaran supaya anakanak tidak bosan. Dalam menanamkan nilai-nilai pendidikan multikultural, seorang guru tidak hanya dituntut untuk mampu secara profesional mengajarkan mata pelajaran yang diampunya akan tetapi harus mampu menanamkan nilai-nilai ke-beragaman yang ada sebagai sekolah inklusi dengan menggunakan pola pola komunikasi yang dapat diterima anak didik mereka. Dalam hal gaya komunikasi dipilih adalah gaya komunikasi yang penuh perhatian, terbuka dan ramah. Guru berupaya menjadi seorang komunikator yang kompeten, seseorang itu harus dapat mengenal keterampilan mana yang diperlukan di dalam situasi tertentu, dengan keterampilan yang dimiliki, termotivasi untuk menggunakan keterampilan dengan baik. Komunikasi terjadi secara transaksional. Setiap pengalaman komunikasi merupakan hasil akumulasi pengalaman yang sebelumnya. Pengalaman baru mempengaruhi pengalaman yang akan datang. Sehingga komunikasi yang terjalin dapat efektif dan berbagi pengertian dengan orang lain.

\section{KESIMPULAN}

$\mathrm{P}$ erlunya kompetensi komunikasi guru ini tertuang dalam lampiran Peraturan Menteri Pendidikan Nasional nomor 16 tahun 2007 tanggal 4 Mei 2007 yang menyatakan bahwa kemampuan berkomunikasi merupakan kemampuan inti ke-7 (tujuh). Kemampuan komunikasi yang baik maka diharapkan dapat meningkatkan kinerja guru dan dengan kemampuan komunikasi yang baik akan mempermudah tranfer of knowledge. Disinilah diperlukan kompetensi komunikasi guru. Kompetensi komunikasi sangat urgent dibutuhkan karena berkaitan dengan tiga hal yaitu Motivation (motivasi), knowledge (pengetahuan), dan skill (ketrampilan). Guru yang memiliki kompetensi komunikasi akan mampu membangun komunikasi sekaligus menanamkan pengaruh positif pada siswanya dalam hal pemahaman nilai-nilai multikultural. $\mathrm{Hal}$ tersebut dilakukan dengan cara mengintegrasikan ke dalam pelajaran integrasi 
pelajaran, memahami siswa yang berbeda, penggunaan metode pembelajaran khusus, pembinaan karakter, dan melatih kerjasama dalam kelompok. Kemampuan komunikasi harus dimiliki seorang guru dalam ranah pembelajaran melalui penanaman nilai-nilai multikultural menjadi ketrampilan yang penting dimiliki oleh guru. Ketrampilan komunikasi pada guru sangat membantu dalam proses kegiatan pembelajaran, terkait dengan kemampuannya dalam mengkomunikasikan gagasan atau ide dalam pembelajaran multikultural dalam bentuk verbal atau non verbal. Guru seharusnya memiliki ketrampilan komunikasi yang baik dan mumpuni sehingga proses penyampaian pesan pembelajaran dapat dengan mudah dipahami para siswa. Guru memiliki gaya komunikasi antara lain penuh perhatian, terbuka dan ramah yang pada akhirnya akan memperlancar proses pembelajaran yang ada. Untuk kajian mendatang perlu di kaji mengenai faktor-faktor yang dapat mempengaruhi kemampuan komunikasi guru atau juga dapat mengukur secara statistik kemampuan komunikasi tersebut.

\section{E. UCAPAN TERIMA KASIH}

U capan Terima kasih disampaikan kepada Prof. Dr. Ernawati Sinaga, M.S., Apt. selaku Ketua LPPM Universitas Nasional Jakarta yang selalu memberikan dorongan untuk aktif dalam penelitian dan Ibu Istiani Nurhasanah selaku Kepala Sekolah dan tim Guru SD Trirenggo Bantul Yogyakarta yang menerima dengan terbuka.

\section{DAFTAR PUSTAKA}

Alfikalia.; Anita Maharani. (2009). Studi Kasus pada Mahasiswa Tingkat Pertama di Universitas Paramadina. Jurnal Ilmu Komunikasi. Vol 6 No 1, hal: 25-44.

Al Hakim, Suparlan; Sri Untari. (2018). Pendidikan Multiultural: Strategi Inovatif Pembelajaran dalam Pluralitas Masyarakat Indonesia. Malang: Madani Media.

Creswell, J. W. (2010). Research Design: Pendekatan Kualitatif, Kuantitatif, Dan Mixed. Yogjakarta: Pt Pustaka Pelajar.

Gunawan, Imam. (2017). Metode Penelitian Kualitatif: Teori \& Praktek.Jakarta: Bumi Aksara

Hamalik, Oemar. (2017). Proses Belajar Mengajar. Jakarta: Bumi Aksara.

Hamdani. (2015). Meningkatkan Pengetahuan Konseptual Dan Pengetahuan Prosedural Mahasiswa Melalui Pendekatan Diskursus Matematik. Jurnal Pendidikan Matematika Dan IPA Vol. 6. No. 1, hal:13-25.

Haryanti, Desi. (2013). Memperbaiki Pengetahuan Dan Kemampuan Prosedural Siswa Melalui Metode Penugasan Berbasis Kesalahan. Pontianak: Tanjungpura

Iriantara, Yosal; Usep Syaripudin. (2018). Komunikasi Pendidikan. Bandung:Simbiosa Rekatama Media.

Purwasito, Andrik. (2015). Komunikasi Multikultural. Yogyakarta: Pustaka Pelajar.

Rahman, A. (2015). Kompetensi Komunikasi Calon Sdm Public Relations. Jurnal Visi Komunikasi. Vol 14, No 2, hal: 255-271.

Sembiring, Lala Septiani; Yantri Maputra. (2015). Mengembangkan Kerjasama (SoftSkill) Melalui Penerapan Metodacooperatif Learning Dan Experiential Learning Dalam Mata Kuliah Psikologi Kewirausahaan. Jurnal Antropologi: Isu-Isu Sosial Budaya (Jantro). Vol 17, No 1, hal: 1-8.

Samovar, Larry A,; Richard E Porter, (2010). Komunikasi Lintas Budaya: Communication Between Cultures. Jakarta: Salemba Humanika.

Smith, J David. (2018). Sekolah Untuk Semua: Teori dan Implementasi Inklusi. Bandung: Nuansa Cendekia.

Wahyudi ; Ratna Krisitiawati. (2018). Gambaran Sekolah Inklusif di Indonesia, (Tinjauan Sekolah Menengah Pertama) Kemendikbud Tahun 2016. Jakarta: Pusat Data dan Statistik Pendidikan dan Kebudayaan

Wulandari, Novita. (2013). Kompetensi Komunikasi Guru dalam Kegiatan Belajar Mengajar Berbasis Student Center Learning di SMA N 9 Semarang. Semarang: Universitas Diponegoro.

Zulqarnain, (2016). Penanaman Nilai-Nilai Pendidikan Multikultural Di Pondok Pesantren D DI-AD Mangkoso Barru Sulawesi Selatan. Jurnal Al-Thariqah Vol. 1, No. 2, hal:193-205.

Zamzami. Lucky,\& Hendrawati. (2014). Kearifan Budaya Lokal Masyarakat Maritim Untuk Upaya Mitigasi Bencana Di Sumatera Barat. Jurnal Antropologi: Isu-Isu Sosial Budaya (Jantro), Vol 16, No 1, hal: $37-48$. 